\title{
INTERLINKAGES BETWEEN EQUITY MARKETS OF G-8 COUNTRIES
}

\author{
HABIB UR REHMAN \\ National University of Modern Languages Islamabad, Pakistan
}

\begin{abstract}
This study attempts to investigate the inter linkages between equity market of G-8 countries. Daily data of stock market returns of G-8 equity markets for the period of 2000 to 2010 has been used. These markets include Canada, France, Germany, Italy, Japan, Russia, United Kingdom and United States. In order to explore the interlinkages among these markets, Granger causality test, Johansen and Juselius Multivariate test, Bi-variate co-integration test, Variance Decomposition and Vector error correction models have been used. The results reveal that co integration exists in equity markets of G-8 countries thus these markets do not offer an opportunity for portfolio diversification to the investors. Further, policy makers of these countries should be careful as the contagious problem may flow to these markets.
\end{abstract}

\section{INTRODUCTION}

The concept of portfolio diversification grabbed much attention in the early work of Harry Markowitz (1952, 59) contributing in the area of investment analysis, and providing bases for the development of famous Modern Portfolio theory. The portfolio return was weighted average of returns of single securities, whereas risk of a portfolio was dependent on the covariance among securities in the portfolio. Sharp (1964) expended the modern portfolio theory and offered famous Capital Asset Pricing Model. This study argued that systematic risk was relevant risk of any portfolio as unsystematic risk would be diversified through formulation of portfolio.

The late twentieth century had been marked by many significant occurrences. The advent of financial liberalization was one such phenomenon. This induced confidence among the investors and they started to invest internationally. A large number of countries also reduced regulations on the financial industry. This provided opportunities to investors to decrease the risks associated with any specific economy. Financial world was reshaped and the entire landscape of financial world was changed. Investors as well as the academicians were becoming more interested in exploring ways to minimize risks. They were indulged in understanding the interlinkages among the markets across the globe. Each market was marked by her distinctive features and characteristics. These characteristics affected the way these markets were interlinked. A large number of studies could be found addressing the linkages among international stock markets especially after the advent of financial liberalization. Technological advancements both in terms of communication services and trading systems had created more opportunities for international portfolio investments. These opportunities provided the investors and policy makers with ways to earn more profits and optimize market interactions. All this was the result of globalization, as it had accelerated the process of integration of financial markets. The emerging markets were seen as the opportunity for portfolio diversification by a large number of international fund managers. The academicians thus extended immense importance to understand the relations amongst international stock markets. An analysis of co movement among different equity markets had been taken a focus with reference to international portfolio diversification. Sharp and Litner (1964) argued that if the co-movement of stock markets was comparable across stock markets, then the gain from the portfolio diversification was not possible. Engle and Granger (1987), Johansen (1988), Johansen and Juselius (1990) presented methods to study the comovement of stock markets. The objective of this study was to understand the dynamic inter-linkages between equity markets of G8. These countries include Canada, UK, USA, Japan, France, Russia, Germany, and Italy. If the markets would be independent then investors can invest to diversify their portfolio and minimize the risks involved.

This study had been divided into four sections. Second section provided an overview of the literature on the topic. The third section reported the data and methodology used. The forth sections encompassed the empirical results. This section is followed by last section that reported the conclusion along with policy implication of the results. 


\section{LITERATURE REVIEW}

The stock market integration had solitary of being an extremely studied area. Kharka, Turan and Kaushik, (2012) found no long-term relationship among Bhutanese stock with Indian as well as other regional stock markets. Al-Zalabani, Sagaran, Menon, and Subha (2012) investigated the co- integration among the foremost Saudi Stock market index (TASI) and other indices like of Hong Kong, India, USA, Japan, Singapore, Malaysia, UK and China. The objective was to study the inter dependence among these indices. TASI reported a significant connection. Sakthivel and Kamaiah (2012) spent efforts toward studying the persuasive inter-linkages connecting European, Asian, and US stock markets for the period of 3rd January 1998 to 30th June 2010. The study examined the short as well as long run relationships by using Johansen-Juselius cointegration, Vector Error Correction models (VECM) and Impulse Response Function (IRF). The results of the co-integration test demonstrate strong co-integration relationship among global stock price indices. The results of Vector Error Correction model reported the linkages of US with some of European and Asian Stock markets.

Aktar (2011) investigated whether there exist any long run association or Granger Causality among Hungarian, Russian and Turkish stock indices or not. Johansen estimation method was used to examine the co- integration between the stock indices. This, acquainted by way of use, was a short run relationship as well as causality along with the stock indices. He located bidirectional causality intended for the Russian and Turkish stock indices. Furthermore, he located that Hungarian stock market did Granger cause Turkish stock market although did not associate and vice versa. Furthermore, Russian stock market did Granger cause Hungarian stock market other than not vice versa. Thus, Russian stock market involves mutually stock markets of Turkey along with Hungary.

Korkmar, Akman (2010) examined the Istanbul Stock Exchange (ISE) and found that it was weak form efficient by selecting two indices from Istanbul Stock Exchange. They analyzed the efficiency by using unit root and co-integration test. Co-integration results subsequently showed that there was no co-integration among indices in the long term. Foreign investors were concerned with emerging economies because of their two objectives i.e. to augment the portfolio expansion and to decrease portfolio risk throughout efficient global portfolio diversification. Modi, Paterek, Son, Vedral, and Williamson (2010) studied a range of different methods to understand the co-movement between some chosen developed stock markets and emerging stock markets of the world. Daily data from July 1, 1997 to June 30, 2008 of Hong Kong (HANGSENG), India (SENSEX), Russia (RTS), Mexico (MXX), Brazil (BVSP), US (DJIA and NASDAQ) and UK (FTSE-100) had been employed and various co-integration method had been engaged to study the short term as well as long-term relationships connecting the markets under study. Harrison and Moore (2010) explored co-movement within five Caribbean stock markets (Jamaica and Barbados, Tobago as well as Trinidad, Bahamas along with Guyana) by means of common factor analysis. The common factors were obtained by principal component analysis along with explanation that was intended for the utmost segment of the variance in the stock exchanges analyzed. Both examined 10-year, 5-year and 3-year periods, and used a vector auto-regression model along with a simple test intended for co-movement among the five markets.

Aktan et al (2009) investigated the emerging markets of Russia, India, Brazil, Argentina (BRICA) and China, and explored the connections among the stock markets and their associations with the US market. The study employed the vector auto regression (VAR) methods to model the interdependencies along with VECM to verify a short-run relationship between these markets. Yalama (2009) examined the relation between Turkey and Brazil's Stock Exchange Markets for the period during 2002 to 2009 . In order to establish causal show model, the study employed Johansen and Juselius (1990) co- integration framework and vector error-correction modeling, along with the Granger Causality Test. The study showed that there was a significant market interrelation between Turkey and Brazil. Time zone problem did not affect this relationship which creates an opportunity for investors to use international hedging strategies and asset allocation.

Mavrakis and Alexakis (2008) explored whether the Greek stock market was integrated with the equity markets of three foremost economies by applying the Johansen-Juselius methodology for the period 19912004. Empirical verifications specified the presence of two long-run relations among the Greek stock market and the equity markets of United Kingdom, Germany and United States. Impressive constraints, resting on the consequential co-integrating vectors, specify single frequent stochastic tendency intended for all cointegrating relations with a high degree of integration among the scrutinized European stock markets.

Coates and Wilson (2007) investigated and found out that there was no association between co- integration and market efficiency hypothesis. As a result, market was efficient in long-run and no arbitrage opportunities were present. However, arbitrage movement passing through the disequilibrium error correction allocated average risk-adjusted returns in the short run. 


\section{RESEARCH METHODOLOGY}

The foremost objective of this study is to test the inter-market relationship among the stock market in G-8 equity markets via (1) correlation matrix (2) co integration test (3) Granger causality (4) Vector error correction Model (5) Variance decomposition. Firstly, unit root tests offered by Phillips (1987); Phillips and Perron (1988) and Augmented Dickey-Fuller recommended by Dickey and Fuller (1979) are used to test the stationary of data. After that, co-integration in the price series of others markets are examined by using Johansen and Juselius Test. The maximum likelihood method is used to find the existence of co -integration vectors in a set of non-stationary time series by Johansen (1988) and Johansen and Juselius (1990). To examine multivariate co-integration, Vector Autoregressive (VAR) is applied. VAR model assumes all the variables in the model are endogenous. Johensen and Juselius approach verified if both the price series are co-integrated in the long run, subsequently the system of equation must be modified by including an Error Correction Term in relation to the short run deviation of prices. If two variables are cointegrated, then Granger causality must exist in at least one direction, which is a consequence of the relationships described by the error-correction model.

\section{Data Description}

Stock index data are taken from daily, weekly, monthly closing prices of equity markets indices for G-8 countries i.e USA, UK, Russia, Japan, Italy, Germany, France, Canada, for the period Jan, 2000 to Dec, 20010. Data is collected through their respective stock exchange and Yahoo finance which is a well-known and reliable source of business information in Pakistan. The daily closing prices of G-8 equity markets indices are taken for the period Jan1, 2000 to Dec 31, 2010, which includes 4016 observations for each country.

TABLE 1

G-8 equity markets indices

\begin{tabular}{ll}
\hline Country Name & Index \\
\hline USA & S\&P 500 Index \\
UK & FTSE 100 \\
Russia & RTS index \\
Japan & NIKKEI 225 \\
Italy & FTSEMIB \\
Germany & DAX \\
Canada & TSX Composite Index \\
France & CAC 40 \\
\hline
\end{tabular}

The continuously compounded rate of return for daily, weekly and monthly bases are used to measure the return for specific period as

$$
\mathrm{Rt}=\ln (\mathrm{Pt} / \mathrm{Pt}-1)
$$

So ' $\mathrm{Rt}$ ' is the continuous compounded return for daily, weekly, monthly ' $\mathrm{t}$ ' and ' $\mathrm{Pt}$ ', 'Pt-1' is representations of closing prices of the equity indices of the G8 used for the daily, weekly, monthly ' $t$ ' and ' $t-1$ ' correspondingly and natural log denoted by ' $L n$ '.

\section{RESEARCH ANALYSIS}

Table 2 reports the results ADF, Phillip-Perron (PP) Test for daily, weekly and Monthly index series. It shows that index series is integrated of order 1 . It shows that the hypothesis of non-stationary in the market returns is rejected. Similarly, the hypothesis of non-stationary in first differences is rejected for all returns.

TABLE 2

Unit root Analysis

\begin{tabular}{lcccr}
\hline & ADF (Level) & $\begin{array}{c}\text { ADF } \\
\text { (Ist Difference) }\end{array}$ & $\begin{array}{c}\text { Phillips-Perron } \\
\text { (level) }\end{array}$ & $\begin{array}{c}\text { Phillips-Perron } \\
\text { (lst Difference) }\end{array}$ \\
\hline Canada & -1.7105 & -66.0444 & -1.61707 & -66.2668 \\
Italy & -1.0513 & -64.6077 & -1.02661 & -64.6159 \\
Germany & -1.5859 & -65.6762 & -1.51462 & -65.7340 \\
Russia & -1.0525 & -57.5806 & -1.04996 & -57.5823 \\
UK & -1.6054 & -32.4253 & -1.61778 & -68.6137 \\
USA & -1.5290 & -49.8563 & -1.52798 & -69.1933 \\
Japan & -0.9590 & -65.6783 & -0.80702 & -65.8335 \\
France & -1.2511 & -66.7664 & -1.09294 & -67.4404 \\
Critical & & & & \\
Values & & & & \\
\multicolumn{1}{c}{$1 \%$} & -3.435654 & -3.435659 & -3.435654 & -3.435659 \\
$\quad 5 \%$ & -2.86377 & -2.863772 & -2.86377 & -2.863772 \\
$10 \%$ & -2.568008 & -2.568009 & -2.568008 & -2.568009 \\
\hline
\end{tabular}

TABLE 3 VAR Lag Order Selection Criteria

\begin{tabular}{lllllll}
\hline Lag & LogL & LR & FPE & AIC & SC & HQ \\
\hline 0 & -247480 & NA & $6.73 \mathrm{E}+43$ & 123.6206 & 123.6331 & 123.6250 \\
1 & -173263 & 148100.5 & $5.52 \mathrm{E}+27$ & 86.58105 & 86.69425 & 86.62117 \\
2 & -172166 & 2185.064 & $3.29 \mathrm{E}+27$ & 86.06497 & $86.2787^{*}$ & 86.14076 \\
\hline
\end{tabular}

The estimation of Johnson and Julius co-integration approach required that there should be appropriate lag length. Schwarz information criterion is used for this purpose. Since the index series are required to be integrated of order 1 so stationary of the data is tested. Johansen's (1991) procedure provides two different 
test statistics that can be used to test the hypothesis of the existence of " $r$ " co integration vectors. The study employs Johansen's (1991) maximum likelihood ratio to examine that indices in question are co-integrated or not. The trace test results of G-8 countries are shown in Table. According to it, there is one cointegration vector between the underlying daily index series and hence long run relationship exists between these indices. The maximal Eigen-value test was used to test the null hypothesis. There are at most $\mathrm{r}$ cointegrating vectors against the alternative of $r+1$ cointegrating vectors. Table reports the result of MaxEigen value test of G- 8 countries stock markets. It shows that there is one co-integrating equation(s) at $\alpha=.05$, hence long runs relationship exists between these indices.

\section{TABLE 4}

Multi-Variate Co integration Analysis Trace Statistics

\begin{tabular}{crrrr}
\hline Eigen value & $\begin{array}{c}\text { Trace } \\
\text { Statistic }\end{array}$ & $\mathbf{5 \% \text { C Value }}$ & P.value & $\begin{array}{c}\text { Hypothesized } \\
\text { Number of } \\
\text { CEs }\end{array}$ \\
\hline 0.014546 & 183.463 & 175.1715 & 0.0171 & None * \\
0.009571 & 124.7064 & 139.2753 & 0.2567 & At most 1 \\
0.007314 & 86.14146 & 107.3466 & 0.5194 & At most 2 \\
0.005102 & 56.70589 & 79.34145 & 0.6972 & At most 3 \\
0.004298 & 36.1927 & 55.24578 & 0.709 & At most 4 \\
0.002338 & 18.92176 & 35.0109 & 0.7725 & At most 5 \\
0.001832 & 9.534881 & 18.39771 & 0.526 & At most 6 \\
0.000544 & 2.182513 & 3.841466 & 0.1396 & At most 7 \\
\hline
\end{tabular}

TABLE 5

Multi-Variate Co integration Analysis Maximum Eigen Statistics

\begin{tabular}{ccccr}
\hline $\begin{array}{c}\text { Eigen } \\
\text { value }\end{array}$ & $\begin{array}{c}\text { Max- } \\
\text { Eigen } \\
\text { Statistic }\end{array}$ & $\begin{array}{c}\text { Critical } \\
\text { Value }\end{array}$ & Prob & $\begin{array}{c}\text { Hypothesized } \\
\text { Number of } \\
\text { CEs }\end{array}$ \\
\hline 0.014546 & 58.75652 & 55.72819 & 0.0242 & None $^{*}$ \\
0.009571 & 38.56498 & 49.58633 & 0.426 & At most 1
\end{tabular}

\begin{tabular}{lllll}
0.007314 & 29.43557 & 43.41977 & 0.6604 & At most 2 \\
0.005102 & 20.51318 & 37.16359 & 0.8781 & At most 3 \\
0.004298 & 17.27094 & 30.81507 & 0.7641 & At most 4 \\
0.002338 & 9.386878 & 24.25202 & 0.9339 & At most 5 \\
0.001832 & 7.352368 & 17.14769 & 0.6744 & At most 6 \\
\hline
\end{tabular}

Bivariate Cointegration analysis is used to explore the relationship between the markets. The trace test results of G-8 countries are shown in Table 6. There are two co-integration vectors between the underlying daily index series and hence long run relationships exist between these indices. Eigen-value test also confirms long runs relationship exists between these indices.

TABLE 6

Bi-Variate Co integration Analysis

\begin{tabular}{cccccc}
\hline & $\begin{array}{c}\text { Eigen } \\
\text { value }\end{array}$ & $\begin{array}{c}\text { Trace } \\
\text { statistics }\end{array}$ & $\begin{array}{c}\mathbf{5 \%} \text { C } \\
\text { Value }\end{array}$ & P.value & $\begin{array}{c}\text { Hypothesized } \\
\text { Number of } \\
\text { CEs }\end{array}$ \\
\hline $\begin{array}{c}\text { CANADA \& } \\
\text { FRANCE }\end{array}$ & 0.0983 & 473.3903 & 18.3977 & 0.0001 & None * \\
& 0.0144 & 58.3721 & 3.8414 & 0.0000 & At most $1 *$ \\
GERMANY & 0.0666 & 280.1194 & 18.3977 & 0.0001 & None * \\
\& ITALY & 0.0008 & 3.35643 & 3.8414 & 0.0669 & At most 1 \\
& 0.0056 & 32.9532 & 18.3977 & 0.0002 & None * \\
$\begin{array}{c}\text { JAPAN \& } \\
\text { RUSSIA }\end{array}$ & 0.0025 & 10.2483 & 3.8414 & 0.0014 & At most 1 * \\
& 0.0804 & 396.981 & 18.3977 & 0.0001 & None * \\
$\begin{array}{c}\text { UK \& } \\
\text { USA }\end{array}$ & 0.0150 & 60.7740 & 3.8414 & 0.0000 & At most 1 * \\
\hline
\end{tabular}

Granger $(1986,1988)$ pointed out that if two variables are co-integrated, then Granger-causality must exist in at least one direction. The test results of Granger Causality between various markets are presented in Table 7. Lag of 2 days is taken to study the effects of one market to another under the assumption of substantial informational efficiency. Results of Granger Causality are reported in Table indicating that there exists unidirectional granger causality between daily G-8countries equity markets.

TABLE 7

Granger Causality Test

\begin{tabular}{lccc}
\hline \multicolumn{1}{c}{ Null Hypothesis } & Obs & F-Statistic & Prob. \\
\hline FRANCE does not Granger Cause CANDIA & 4013 & 38.5559 & $3.00 \mathrm{E}-17$ \\
CANDIA does not Granger Cause FRANCE & & 25.9044 & $7.00 \mathrm{E}-12$ \\
& & & \\
GERMANY does not Granger Cause CANDIA & 4013 & 18.7378 & $8.00 \mathrm{E}-09$ \\
CANDIA does not Granger Cause GERMANY & & 32.1769 & $1.00 \mathrm{E}-14$ \\
& & & \\
ITALY does not Granger Cause CANDIA & 4013 & 18.0797 & $2.00 \mathrm{E}-08$ \\
CANDIA does not Granger Cause ITALY & & 10.3505 & $3.00 \mathrm{E}-05$
\end{tabular}


JAPAN does not Granger Cause CANDIA

CANDIA does not Granger Cause JAPAN

RUSSIA does not Granger Cause CANDIA

CANDIA does not Granger Cause RUSSIA

UK does not Granger Cause CANDIA

CANDIA does not Granger Cause UK

USA does not Granger Cause CANDIA

CANDIA does not Granger Cause USA

GERMANY does not Granger Cause FRANCE

FRANCE does not Granger Cause GERMANY

ITALY does not Granger Cause FRANCE

FRANCE does not Granger Cause ITALY

JAPAN does not Granger Cause FRANCE

FRANCE does not Granger Cause JAPAN

RUSSIA does not Granger Cause FRANCE

FRANCE does not Granger Cause RUSSIA

UK does not Granger Cause FRANCE

FRANCE does not Granger Cause UK

USA does not Granger Cause FRANCE

FRANCE does not Granger Cause USA

ITALY does not Granger Cause GERMANY

GERMANY does not Granger Cause ITALY

JAPAN does not Granger Cause GERMANY

GERMANY does not Granger Cause JAPAN

RUSSIA does not Granger Cause GERMANY

GERMANY does not Granger Cause RUSSIA

UK does not Granger Cause GERMANY

GERMANY does not Granger Cause UK

USA does not Granger Cause GERMANY

GERMANY does not Granger Cause USA
4013

180.841

$6.00 \mathrm{E}-76$

1.63056

0.196

4013

134.532

3.33891

$3.00 \mathrm{E}-57$

0.0356

4013

38.668

2.00E-17

35.6906

$4.00 \mathrm{E}-16$

4013

32.7456

8.00E-15

61.7507

$4.00 \mathrm{E}-27$

4013

15.9201

$1.00 \mathrm{E}-07$

23.5124

$7.00 \mathrm{E}-11$

4013

12.3321

4.42437

5.00E-06

0.012

4013

291.947

4.00E-119

2.82144

0.0596

4013

40.7349

$3.00 \mathrm{E}-18$

3.89389

0.0204

4013

32.964

6.00E-15

8.20798

0.0003

4013

35.2751

7.00E-16

188.398

$6.00 \mathrm{E}-79$

4013

13.1733

2.00E-06

0.85697

0.4245

4013

307.168

8.00E-12

0.46536

0.6279

4013

46.5057

1.00E-20

9.91387

5.00E-05

4013

53.801

$9.00 \mathrm{E}-24$

12.7426

3.00E-06

4013

42.2056

7.00E-19

95.6337

3.00E-41 
JAPAN does not Granger Cause ITALY

ITALY does not Granger Cause JAPAN

RUSSIA does not Granger Cause ITALY

ITALY does not Granger Cause RUSSIA

UK does not Granger Cause ITALY

ITALY does not Granger Cause UK

USA does not Granger Cause ITALY

ITALY does not Granger Cause USA

RUSSIA does not Granger Cause JAPAN

JAPAN does not Granger Cause RUSSIA

UK does not Granger Cause JAPAN

JAPAN does not Granger Cause UK

USA does not Granger Cause JAPAN

JAPAN does not Granger Cause USA

UK does not Granger Cause RUSSIA

RUSSIA does not Granger Cause UK

USA does not Granger Cause RUSSIA

RUSSIA does not Granger Cause USA

USA does not Granger Cause UK

UK does not Granger Cause USA

\begin{tabular}{|c|c|c|}
\hline \multirow[t]{2}{*}{4013} & 80.2921 & $6.00 \mathrm{E}-35$ \\
\hline & 2.36053 & 0.0945 \\
\hline \multirow[t]{2}{*}{4013} & 15.0536 & $3.00 \mathrm{E}-07$ \\
\hline & 0.97408 & 0.3776 \\
\hline \multirow[t]{2}{*}{4013} & 3.32476 & 0.0361 \\
\hline & 4.81095 & 0.0082 \\
\hline \multirow[t]{2}{*}{4013} & 8.72929 & 0.0002 \\
\hline & 46.8527 & $8.00 \mathrm{E}-21$ \\
\hline \multirow[t]{2}{*}{4013} & 28.2281 & $7.00 \mathrm{E}-13$ \\
\hline & 101.405 & $1.00 \mathrm{E}-43$ \\
\hline \multirow[t]{2}{*}{4013} & 5.48201 & 0.0042 \\
\hline & 215.56 & $1.00 \mathrm{E}-89$ \\
\hline \multirow[t]{2}{*}{4013} & 4.24381 & 0.0144 \\
\hline & 375.165 & $4.00 \mathrm{E}-15$ \\
\hline \multirow[t]{2}{*}{4013} & 0.56539 & 0.5682 \\
\hline & 58.6576 & $8.00 \mathrm{E}-26$ \\
\hline \multirow[t]{2}{*}{4013} & 1.79435 & 0.1664 \\
\hline & 90.029 & $6.00 \mathrm{E}-39$ \\
\hline \multirow[t]{2}{*}{4013} & 21.7063 & $4.00 \mathrm{E}-10$ \\
\hline & $7.00 \mathrm{E}-81$ & 193.39 \\
\hline
\end{tabular}

The result of VECM model shows that the short term disequilibrium is mostly adjusted in one period of time.

TABLE 8

Vector Error Correction Model

\begin{tabular}{lcccccccc}
\hline & Canada & France & Germany & \multicolumn{1}{l}{ Italy } & Japan & \multicolumn{1}{l}{ Russia } & UK & \multicolumn{2}{l}{ USA } \\
\hline ECT & -0.10403 & -0.21983 & -0.99301 & -0.84259 & -0.694 & -0.82189 & -0.936 & -0.509 \\
S.E & -0.00484 & -0.00317 & -0.01563 & -0.03526 & 0.0218 & -0.03222 & -0.017 & -0.023 \\
t Statistics & {$[-21.51]$} & {$[-69.31]$} & {$[-63.54]$} & {$[-23.89]$} & {$[-31.7]$} & {$[-25.50]$} & {$[-55.1]$} & {$[-21.3]$} \\
\hline
\end{tabular}

The variance decomposition indicates the amount of information each variable contributes to the other variables in the auto-regression. It determines how much of the forecast error variance of each of the variables can be explained by exogenous shocks to the other variables.

TABLE 9

Variance Decomposition

\begin{tabular}{lrrrrrrrrr}
\hline Period & S.E. & CANADA & FRANCE & GERMANY & \multicolumn{1}{c}{ ITALY } & JAPAN & RUSSIA & \multicolumn{1}{c}{ UK } & \multicolumn{2}{c}{ USA } \\
\hline 1 & $2.93 \mathrm{E}-17$ & 100 & 0 & 0 & 0 & 0 & 0 & 0 & 0 \\
2 & $2.93 \mathrm{E}-17$ & 100 & $1.20 \mathrm{E}-28$ & $1.03 \mathrm{E}-28$ & $2.35 \mathrm{E}-29$ & $9.73 \mathrm{E}-30$ & $1.98 \mathrm{E}-29$ & $3.72 \mathrm{E}-29$ & $6.77 \mathrm{E}-30$ \\
3 & $2.93 \mathrm{E}-17$ & 100 & $1.33 \mathrm{E}-28$ & $1.27 \mathrm{E}-28$ & $2.46 \mathrm{E}-29$ & $1.29 \mathrm{E}-29$ & $2.03 \mathrm{E}-29$ & $4.28 \mathrm{E}-29$ & $1.07 \mathrm{E}-29$
\end{tabular}




\begin{tabular}{llllllllll}
4 & $2.93 \mathrm{E}-17$ & 100 & $1.33 \mathrm{E}-28$ & $1.27 \mathrm{E}-28$ & $2.46 \mathrm{E}-29$ & $1.29 \mathrm{E}-29$ & $2.03 \mathrm{E}-29$ & $4.28 \mathrm{E}-29$ & $1.07 \mathrm{E}-29$ \\
5 & $2.93 \mathrm{E}-17$ & 100 & $1.33 \mathrm{E}-28$ & $1.27 \mathrm{E}-28$ & $2.46 \mathrm{E}-29$ & $1.29 \mathrm{E}-29$ & $2.03 \mathrm{E}-29$ & $4.28 \mathrm{E}-29$ & $1.07 \mathrm{E}-29$ \\
6 & $2.93 \mathrm{E}-17$ & 100 & $1.33 \mathrm{E}-28$ & $1.27 \mathrm{E}-28$ & $2.46 \mathrm{E}-29$ & $1.29 \mathrm{E}-29$ & $2.03 \mathrm{E}-29$ & $4.28 \mathrm{E}-29$ & $1.07 \mathrm{E}-29$ \\
7 & $2.93 \mathrm{E}-17$ & 100 & $1.33 \mathrm{E}-28$ & $1.27 \mathrm{E}-28$ & $2.46 \mathrm{E}-29$ & $1.29 \mathrm{E}-29$ & $2.03 \mathrm{E}-29$ & $4.28 \mathrm{E}-29$ & $1.07 \mathrm{E}-29$ \\
8 & $2.93 \mathrm{E}-17$ & 100 & $1.33 \mathrm{E}-28$ & $1.27 \mathrm{E}-28$ & $2.46 \mathrm{E}-29$ & $1.29 \mathrm{E}-29$ & $2.03 \mathrm{E}-29$ & $4.28 \mathrm{E}-29$ & $1.07 \mathrm{E}-29$ \\
9 & $2.93 \mathrm{E}-17$ & 100 & $1.33 \mathrm{E}-28$ & $1.27 \mathrm{E}-28$ & $2.46 \mathrm{E}-29$ & $1.29 \mathrm{E}-29$ & $2.03 \mathrm{E}-29$ & $4.28 \mathrm{E}-29$ & $1.07 \mathrm{E}-29$ \\
10 & $2.93 \mathrm{E}-17$ & 100 & $1.33 \mathrm{E}-28$ & $1.27 \mathrm{E}-28$ & $2.46 \mathrm{E}-29$ & $1.29 \mathrm{E}-29$ & $2.03 \mathrm{E}-29$ & $4.28 \mathrm{E}-29$ & $1.07 \mathrm{E}-29$ \\
\hline
\end{tabular}

\section{CONCLUSION}

The augmented Dickey-Fuller and PhillipsPerron tests on the market index levels and their first differences showed that the hypothesis of non-stationary in the market indices cannot be rejected. However, the hypothesis of non-stationary in the first differences was rejected for all markets implying that the variables are integrated of order one. Since the index series are found to be non-stationary, the study examined Cointegration using Johansen's (1991) procedure. For this purpose Trace statistics is used. From results, it is evident that there is one co-integrating vector between underlying daily series and hence there is long run equilibrium. Pair-wise co-integration analysis also shows that cointegration exists between G-8 countries. Multivariate co-integration analysis also confirms the same results Granger causality test also confirms unidirectional bidirectional causality between G-8 markets.

\section{REFERENCES}

Al-Zalabani, A. M., Sagaran, S., Menon, N. R., \& Subha, M. V. 2012. Co-integration of the saudi arabian stock market with other markets from emerging and developed economies. Pakistan business review, 615 .

Coates, D., \& Wilson, B. 2007. Interest group activity and long-run stock market performance. Public Choice, 133(3-4), 343-358.

Dickey, D. A., \& Fuller, W. A. 1979. Distribution of the estimators for autoregressive time series with a unit root. Journal of the American statistical association, 74(366a), 427-431.

Engle, R. F., \& Granger, C. W. 1987. Co-integration and error correction: representation, estimation, and testing. Econometrica: journal of the Econometric Society, 251-276.

Granger, C. W. 1986. Developments in the study of cointegrated economic variables. Oxford Bulletin of economics and statistics, 48(3), 213-228.

Granger, C. W. 1988. Some recent development in a concept of causality. Journal of econometrics, 39(1), 199-211.
Harrison, B., \& Moore, W. 2010. Stock Market CoMovement in the Caribbean. Economic Issues, 15(1).

Johansen, S. 1988. Statistical analysis of cointegration vectors. Journal of economic dynamics and control, 12(2), 231-254.

Johansen, S., \& Juselius, K. 1990. Maximum likelihood estimation and inference on co-integration - with applications to the demand for money. Oxford Bulletin of Economics and statistics, 52(2), 169210.

Kharka, D. S., Turan, M. S., \&Kaushik, K. P. 2012. Stock Market Integration in South Asia. International Journal of Management \& Information Technology, 1(2), 8-20.

Korkmaz, M., \&Akman, G. 2010. Testing the weak form market efficiency on Istanbul stock exchange. Trakia J. Sci, 8(3), 39-49.

Maddala, G. S., \& Wu, S. 1999. A comparative study of unit root tests with panel data and a new simple test. Oxford Bulletin of Economics and statistics, 61(S1), 631-652.

Markowitz, H. 1952. Portfolio selection*. The journal of finance, 7(1), 77-91.

Markowitz, H. M. 1991. Foundations of portfolio theory. The Journal of Finance, 46(2), 469-477.

Mavrakis, E., \& Alexakis, C. 2008. Market Performance Effects on Pairs Trading Strategies: Evidences on Banks' Equity Shares in Germany and Greece.

Modi, K., Paterek, T., Son, W., Vedral, V., \& Williamson, M. 2010. Unified view of quantum and classical correlations. Physical review letters, 104(8), 080501.

Pedroni, P. 1999. Critical values for cointegration tests in heterogeneous panels with multiple regressors. Oxford Bulletin of Economics and statistics,61(S1), 653-670.

Pedroni, P. 2001. Purchasing power parity tests in cointegrated panels. Review of Economics and Statistics, 83(4), 727-731.

Pedroni, P. 2004. Panel cointegration: asymptotic and finite sample properties of pooled time series tests with an application to the PPP hypothesis. Econometric theory, 20(03), 597-625. 
Perron, P., \& Vogelsang, T. J. 1992.Testing for a unit root in a time series with a changing mean: corrections and extensions. Journal of Business \& Economic Statistics, 10(4), 467-470.

Phillips, P. C. 1987. Towards a unified asymptotic theory for autoregression. Biometrika, 74(3), 535547.

Phillips, P. C., \& Perron, P. 1988. Testing for a unit root in time series regression. Biometrika, 75(2), 335-346.
Sakthivel, P., \& Kamaiah, B. 2012. Interlinkages among Asian, European and the US Stock Markets: A Multivariate Cointegration Analysis. Journal of Economics \& Behavioral Studies, 4(3).

Sharpe, W. F. 1964. Capital Asset Prices: A Theory Of Market Equilibrium Under Conditions Of Risk*. The journal of finance, 19(3), 425-442.

Yalama, A. 2009. Stock market linkages in emerging markets: evidence from Turkey and Brazil. Banks and Bank Systems, 4(3), 73-80. 